УДК 33.021[657.411.005.5]

DOI: $10.15673 /$ fie.v12i4.1913

Купріна Н.М.

кандидат економічних наук, доцент кафедра обліку та аудиту

E-mail:k.natali_@ukr.net

ORCID ID: 0000-0003-4645-545X

Пчелянська Г.Б.

старший викладач

кафедра обліку та аудиту

E-mail: gaya_od@ukr.net

ORCID ID: 0000-0003-0944-986X
Васьковська К.О.

кандидат економічних наук, доцент кафедра обліку та аудиту

E-mail: v.caterin17@gmail.com

ORCID ID: 0000-0001-8093-170X

Величко О.M.

студентка 3 курсу факультету економіки, бізнесу і контролю

Одеська національна академія харчових технологій вул. Канатна 112, м. Одеса, Україна, 65039

E-mail: velichko20012001@gmail.com ORCID ID: 0000-0002-8591-878X

\title{
ОБОРОТНІ АКТИВИ ПІДПРИЄМСТВА: АСПЕКТИ БУХГАЛТЕРСЬКОГО ОБЛІКУ ЗА НАЦІОНАЛЬНИМИ ТА МІЖНАРОДНИМИ СТАНДАРТАМИ ТА ÏХ КЛАСИФІКАЦІЯ
}

Актуальним аспектом в сучасних умовах $є$ продовження реформування системи бухгалтерського обліку в Україні за міжнародними стандартами, що пов'язано з інтеграційними процесами на всіх рівняє фрункціонування економічних суб'єктів та державної політики й її регулювання. В даної публікації проведено дослідження та проаналізовано підходи до визначення сутності категорій «оборотні активи» та їх елементів - «грошові кошти», «запаси», «дебіторська заборгованість» за матеріалами публікацій вчених та національними та міжнародними стандартами, визначено спільні риси та відмінності, в тому числі у складі елементів, підходів в їх оцінки, аспектів відображення у фінансової звітності. Досліджено підходи до класифікації оборотних активів за різними ознаками, цілями управління, та структурними елементами. Підкреслено, що в сучасних умовах функціонування підприємств важливим $є$ така класифікація оборотних активів, що спряє їх ефективному управлінню, платоспроможності підприємства, збільшення ліквідності його активів, зменшення ризиків та підвищення ефективності використання оборотного капіталу, що вкладено в його оборотні активи.

Ключові слова: оборотні активи, елементи оборотних активів, класифікація, стандарти бухгалтерського обліку, грошові кошти, запаси, дебіторська заборгованість.

This work is licensed under a Creative Commons Attribution 4.0 International License http://creativecommons.org/licenses/by/4.0/

Постановка проблеми та її зв'язок з важливими науковими та практичними завданнями. Процеси глобалізації, які суттєво впливають з 20 сторіччя на стан та розвиток національних економік та їх суб'єктів на теперішній час зумовлюють інтеграційні та інтернаціоналізаційні процеси в економіці країн та регіонів, що обумовлено розширенням зовнішньоекономічних відносин між країнами та забезпечує їх міжнародне співробітництво в багатьох напрямках. В останні десятиріччя Україна проводила активну політику інтеграції в європейську спільноту, у зв’язку з цим суттєвою стала проблема узгодженості національних та міжнародних положень, законів, нормативно-правових актів усіх сфер та галузей діяльності. Таким особливим питанням $\epsilon$, наприклад, формування облікової політики на підприємствах, на підставі якої визначаються основні питання щодо ведення бухгалтерського обліку, складання та подання фінансової звітності, визначається перелік активів і пасивів, які знаходяться у його розпорядженні.

Процес реформації національних положень (стандартів) бухгалтерського обліку (НП(С)БО) до міжнародних $(\mathrm{M}(\mathrm{C})$ БО) розпочався в Україні вже давно і триває надалі, тому дуже важливо враховувати їх відмінності при виборі облікової політики підприємства. В Кабінетом міністрів України визначено перелік підприємств та організацій, які мають право використовувати міжнародні стандарти, наприклад, страхові компанії, публічні акціонерні товариства, а також емітенти цінних паперів тощо. Тому, на теперішній час пріоритетним залишається завдання надання зовнішнім та внутрішнім користувачам своєчасних, неупереджених, достовірних даних про фінансовий стан, результати усіх видів діяльності, напрямки надходження, використання та витрачання грошових коштів підприємства. Саме грошові кошти, як найбільш ліквідні активи та частина оборотних активів відіграють значну роль в діяльності будь-якого підприємства, оскільки забезпечують плато- та кредитоспроможність, здатні показати інвесторам фінансову надійність підприємства, в яке вони вкладають свої фінансові ресурси, що підтверджує актуальність 
обраного напряму дослідження.

Аналіз останніх досліджень і публікацій. Дослідження вітчизняними та зарубіжними вченими аспектів обліку та його розвитку в сучасних умовах відображені у методичних та практичних працях, наукових публікаціях, таких вчених як: П.Й. Атамаса, Ф.Ф. Бутинця, М.Т. Білухі, С.Ф. Голова, О.Г. Лищенко, Л.В. Нападовської, М.С. Пушкар, В.С. Рудницького, В.В. Сопка, М.Г. Чумаченка, А.Д. Шеремета та ін. Дослідження сутності оборотних активів, питання їх класифікації та управління відображені в працях українських та зарубіжних вчених: Баумоля У., Білик М.Д., Бланка I.О., Брейлі Р., Бубняк I.М., Бутинець Т.А., Бутинця Ф.Ф., Буркинського Б.В., Бутенко А.І., Ганіна В.І., Демченко Т.А., Доніна С.О., Ермасової Н.Б., Зві Боді, Канцедал Н.Ю., Кірєйцева Г.Г., Клімович I.М., Ковальова В.В., Купалової Г.І., Любенко Н.М., Майєрса С., Матвіюк А.В., Мертона Р., Міллера М., Нашкерської Г.В., Невмержицької Н.Ю., Носова П.Л., Орра Д., Павловської О.В., Притуляк Н.М., Савченко А.М., Слав'юк Р.А., Тарасенко О.І., Томкінса Д., Ярошевич Н.Б., але й не втрачають своєї актуальності у теперішній час та потребують додаткових досліджень у зв'язку зі змінами в організації бухгалтерського обліку на підприємствах України на підставі НП(С)БО та М(С)БО.

Формулювання цілей дослідження. Метою даної статті є дослідження аспектів НП(С)БО та М(С)БО, які пов'язані з питаннями організації обліку оборотних активів та відображення їх у фінансовій звітності, визначення підходів до сутності та класифікації даного об'єкту дослідження для ефективного їх обліку та управління.

Виклад основних результатів та їх обгрунтування. Діяльність будь-якого підприємства починається 3 формування активів, які утворюються за рахунок власного та залученого капіталу. Саме без активів неможливо уявити господарську діяльність жодного підприємства або організації. Згідно 3 НП(С)БО 1 «Загальні вимоги до фінансової звітності» актив - це «ресурси, контрольовані підприємством в результаті минулих подій, використання яких, як очікується, приведе до надходження економічних вигід у майбутньому» [1]

Національне положення (стандарт) бухгалтерського обліку 1 «Загальні вимоги до фінансової звітності» (НП(С)БО 1) визначає, що оборотні активи - це «гроші та їх еквіваленти, що не обмежені в використанні, а також інші активи, що призначені для реалізації та використання, протягом операційного циклу чи протягом дванадцяті місяців 3 дати балансу» [1]. Тобто всі активи, що не є оборотними, належать до необоротних [1], але існують й інші трактування цього поняття авторами (табл. 1).

Таблиця 1

Дослідження сутності поняття «оборотні активи»*

\begin{tabular}{|c|c|}
\hline Автор, джерело & Визначення \\
\hline $\begin{array}{l}\text { Слав'юк Р.А. } \\
{[2, \text { с.4] }}\end{array}$ & $\begin{array}{l}\text { Оборотні активи - ресурси, які належать підприємству і які напевно буде перетво- } \\
\text { рено на гроші чи використано іншим чином протягом року з дати складання бухга- } \\
\text { лтерського балансу. }\end{array}$ \\
\hline $\begin{array}{l}\text { Нашкерська Г.В. } \\
{[3, \text { с.317] }}\end{array}$ & $\begin{array}{l}\text { Оборотні активи - це грошові кошти, що вкладені для створення оборотних вироб- } \\
\text { ничих фондів та фондів обігу з метою забезпечення безперервного процесу вироб- } \\
\text { ництва і реалізації продукції. }\end{array}$ \\
\hline $\begin{array}{l}\text { Демченко Т.А., } \\
{[4, \text { с.179] }}\end{array}$ & $\begin{array}{l}\text { Оборотні активи - це сукупність оборотних фондів та фондів обігу, які використо- } \\
\text { вуються для фінансування поточної господарської діяльності і виражені у грошовій } \\
\text { формі. }\end{array}$ \\
\hline $\begin{array}{l}\text { Ковальов В.В. } \\
{[5, \text { с.256] }}\end{array}$ & $\begin{array}{l}\text { Оборотні активи - активи, що споживаються в ході виробничого процесу протягом } \\
\text { року або звичайного операційного циклу, що перевищує } 12 \text { місяців через специфіку } \\
\text { технологічного виробництва, і тому такі, що повністю переносять свою вартість } \\
\text { виготовленої продукції. }\end{array}$ \\
\hline $\begin{array}{l}\text { Бланк I.O. } \\
{[6, \text { с.162] }}\end{array}$ & $\begin{array}{l}\text { Оборотні активи - сукупність майнових цінностей підприємства, що забезпечують } \\
\text { поточну виробничо-комерційну діяльність підприємства та, що повністю спожив- } \\
\text { ються в процесі одного виробничо-комерційного циклу. }\end{array}$ \\
\hline $\begin{array}{l}\text { Ермасова Н.Б. } \\
{[7, \text { c. } 78]}\end{array}$ & $\begin{array}{l}\text { Оборотні активи - це засоби, інвестовані підприємством в поточні операції під час } \\
\text { кожного операційного циклу. }\end{array}$ \\
\hline $\begin{array}{l}\text { Кірєйцев Г.Г. } \\
{[8, \text { с.106] }}\end{array}$ & $\begin{array}{l}\text { Оборотні активи - це сукупність коштів, авансованих в оборотні виробничі фонди і } \\
\text { фонди обігу для забезпечення безперервності процесу виробництва та реалізації } \\
\text { продукції. }\end{array}$ \\
\hline Бутинець Ф.Ф. [9] & $\begin{array}{l}\text { Оборотні активи - сукупність майнових цінностей підприємства, що обслуговують } \\
\text { поточний господарський процес, які повністю споживаються протягом одного опе- } \\
\text { раційного циклу. }\end{array}$ \\
\hline $\begin{array}{l}\text { Брейлі Р., Майєрс С. } \\
{[10, \text { c.740] }}\end{array}$ & $\begin{array}{l}\text { Оборотні активи - це такі активи, які компанія в найближчому майбутньому збира- } \\
\text { ється перетворити в грошові кошти. }\end{array}$ \\
\hline $\begin{array}{l}\text { Боді 3., Мертон Р. } \\
{[11, \text { c.114] }}\end{array}$ & $\begin{array}{l}\text { Оборотні активи - суми грошових коштів компанії та всі інші статті балансу, які } \\
\text { протягом року передбачається перетворити в гроші. }\end{array}$ \\
\hline
\end{tabular}

*Сформовано на підставі джерел [2-11] 
Дослідження показало, що поняття «оборотні активи» в сучасному визначенні був трансформований за часом розвитку економічних суб'єктів з ходом історії та сформувався 3 понять «оборотні кошти» та призвів до виникнення нових - «поточні активи», «оборотні активи» та «оборотний капітал».

Існують різноманітна класифікація активів, але основна 3 них поділяє їх в залежності від характеру участі в процесі обороту на оборотні і необоротні, за елементами їх формування та фінансування. Так, в міжнародній практиці кожне підприємство, враховуючи характер діяльності та особливості технології й організації господарських операцій самостійно вирішує питання поділу активів на оборотні та необоротні. В Україні відповідно до НП(С)БО на оборотні та необоротні є обов'язковим [1]. Щодо підходів до класифікації оборотних активів, то вона нараховує в залежності від ознаки в собі велику кількість елементів (табл. 2), але незважаючи на це, вибір їх базується на принципах ефективного керівництва, що дозволяє підприємству ефективно функціонувати та бути фінансово стійкім та забезпечити конкурентоспроможність.

Таблиця 2

Підходи вчених до класифікації оборотних активів підприсмства*

\begin{tabular}{|c|c|c|c|}
\hline \multirow[b]{2}{*}{ Автор } & \multicolumn{3}{|c|}{ Класифікації оборотних активів } \\
\hline & $\begin{array}{c}\text { Класифікаційна } \\
\text { ознака }\end{array}$ & \multicolumn{2}{|c|}{ Види оборотних активів } \\
\hline \multirow{12}{*}{$\begin{array}{l}\text { Тарасенко O.I., } \\
\text { Любенко Н.M. } \\
\text { [12] }\end{array}$} & $\begin{array}{l}\text { Формування і ре- } \\
\text { гулювання окре- }\end{array}$ & $\begin{array}{l}\text { Оборотні активи у сфері } \\
\text { виробництва } \\
\text { (оборотні фонди) }\end{array}$ & $\begin{array}{l}\text { - виробничі зап аси } \\
\text { - незавершене виробництво } \\
\text { - напівфабрикати власного виробницт- } \\
\text { ва } \\
\text { - витрати майбутніх періодів }\end{array}$ \\
\hline & $\begin{array}{c}\text { мих елементів } \\
\text { оборотних активів }\end{array}$ & $\begin{array}{l}\text { Оборотні активи у сфері } \\
\text { обігу } \\
\text { (фонди обігу) }\end{array}$ & $\begin{array}{l}\text { - залишки готової продукції на складах } \\
\text { - продукція відвантажена } \\
\text { - грошові кошти на рахунку та в касі } \\
\text { - дебіторська заборгованість } \\
\text { - інші }\end{array}$ \\
\hline & \multirow{6}{*}{$\begin{array}{l}\text { В обліку і звітнос- } \\
\text { ті оборотні активи } \\
\text { виділяють }\end{array}$} & Запаси & $\begin{array}{l}\text { - виробничі запаси } \\
\text { - незавершене виробництво } \\
\text { - запаси готової продукції } \\
\text { - товари, придбані } 3 \text { метою перепродажу }\end{array}$ \\
\hline & & $\begin{array}{l}\text { Дебіторська заборгова- } \\
\text { ність }\end{array}$ & $\begin{array}{l}\text { - за товари } \\
\text { - роботи } \\
\text { - послуги } \\
\end{array}$ \\
\hline & & $\begin{array}{l}\text { Дебіторська заборгова- } \\
\text { ність за розрахунками }\end{array}$ & $\begin{array}{l}\text { - } 3 \text { бюджетом } \\
\text { - за виданими авансами } \\
\text { - за нарахованими доходами } \\
\text { - за внутрішніми розрахунками } \\
\text { - інша }\end{array}$ \\
\hline & & \multicolumn{2}{|c|}{ Поточні фінансові інвестиції } \\
\hline & & $\begin{array}{l}\text { Грошові кошти та їх екві- } \\
\text { валенти }\end{array}$ & $\begin{array}{l}\text { - в національній валюті } \\
\text { - в іноземній валюті }\end{array}$ \\
\hline & & \multicolumn{2}{|l|}{ Інші оборотні активи } \\
\hline & \multirow{2}{*}{$\begin{array}{c}\text { За характером } \\
\text { участі в операцій- } \\
\text { ному процесі }\end{array}$} & $\begin{array}{l}\text { Оборотні активи, що об- } \\
\text { слуговують виробничий } \\
\text { цикл підприємства }\end{array}$ & $\begin{array}{l}\text { - запаси сировини, матеріалів і напів- } \\
\text { фабрикатів } \\
\text { - обсяг незавершеного виробництва } \\
\text { - запаси готової продукції }\end{array}$ \\
\hline & & $\begin{array}{l}\text { Оборотні активи, що об- } \\
\text { слуговують фінансовий } \\
\text { (грошовий) цикл підпри- } \\
\text { ємства }\end{array}$ & $\begin{array}{l}\text { - дебіторська заборгованість } \\
\text { - } \text { грошові кошти } \\
\text { - } \text { тощо }\end{array}$ \\
\hline & \multirow{2}{*}{$\begin{array}{l}\text { За періодом функ- } \\
\text { ціонування оборо- } \\
\text { тних активів }\end{array}$} & $\begin{array}{l}\text { Постійна (системна) час- } \\
\text { тина оборотних активів }\end{array}$ & $\begin{array}{l}\text { являє собою незмінну частину, яка не } \\
\text { залежить від сезонних та інших коли- } \\
\text { вань обсягів операційної діяльності під- } \\
\text { приємства }\end{array}$ \\
\hline & & $\begin{array}{l}\text { Змінна частина оборотних } \\
\text { активів }\end{array}$ & $\begin{array}{l}\text { являє собою варіативну їх частину, яка } \\
\text { пов'язана із сезонним зростанням обся- } \\
\text { гу виробництва і реалізації продукції }\end{array}$ \\
\hline
\end{tabular}




\begin{tabular}{|c|c|c|c|}
\hline \multirow[b]{3}{*}{ Автор } & & & Продовження таб. \\
\hline & \multicolumn{3}{|c|}{ Класифікації оборотних активів } \\
\hline & $\begin{array}{c}\text { Класифікаційна } \\
\text { ознака }\end{array}$ & \multicolumn{2}{|c|}{ Види оборотних активів } \\
\hline \multirow{3}{*}{$\begin{array}{l}\text { Тарасенко О.I. } \\
\text { Любенко Н.M. } \\
{[12]}\end{array}$} & \multirow{3}{*}{$\begin{array}{c}\text { В залежності від } \\
\text { здатності до шви- } \\
\text { дкого перетворен- } \\
\text { ня в грошові кош- } \\
\text { ти (ліквідності) }\end{array}$} & Високоліквідні активи & грошові кошти та їх еквіваленти \\
\hline & & Середньоліквідні активи & $\begin{array}{l}\text { - товари відвантажені } \\
\text { - дебіторська заборгованість }\end{array}$ \\
\hline & & Низьколіквідні активи & $\begin{array}{l}\text { - виробничі запаси } \\
\text { - готова продукція на складі } \\
\text { - незавершене виробництво } \\
\text { - витрати майбутніх періодів }\end{array}$ \\
\hline \multirow{11}{*}{$\begin{array}{c}\text { Білик М.Д., Па- } \\
\text { вловська О.В., } \\
\text { Притуляк Н.М., } \\
\text { Невмержицька } \\
\text { Н.Ю. [13] }\end{array}$} & \multirow{2}{*}{$\begin{array}{c}\text { За фінансовими } \\
\text { особливостями } \\
\text { формування }\end{array}$} & Валові & \multirow[t]{2}{*}{ поширена у зарубіжній практиці } \\
\hline & & Чисті & \\
\hline & \multirow{2}{*}{ За належністю } & \multicolumn{2}{|l|}{ Власні } \\
\hline & & \multicolumn{2}{|l|}{ Позикові (залучені) } \\
\hline & \multirow{3}{*}{$\begin{array}{l}\text { За рівнем ліквід- } \\
\text { ності }\end{array}$} & Абсолютно ліквідні активи & $\begin{array}{ll}\text { - } & \text { гроші в касі } \\
\text { - } & \text { гроші на поточних рахунках у банку }\end{array}$ \\
\hline & & $\begin{array}{l}\text { Швидколіквідні } \\
\text { активи }\end{array}$ & $\begin{array}{l}\text { усі форми дебіторської заборгованості } \\
\text { на користь підприємства, крім безна- } \\
\text { дійної }\end{array}$ \\
\hline & & $\begin{array}{ll}\text { Низьколіквідні } \\
\text { активи }\end{array}$ & $\begin{array}{l}\text { запаси товарно-матеріальних ціннос- } \\
\text { тей у різних формах }\end{array}$ \\
\hline & \multirow{2}{*}{$\begin{array}{c}\text { За формами функ- } \\
\text { ціонування у кон- } \\
\text { кретному періоді } \\
\text { часу }\end{array}$} & Матеріальні & $\begin{array}{l}\text { - сировина } \\
\text { - матеріали напівфабрикати } \\
\text { - незавершене виробництво } \\
\text { - готова продукція } \\
\end{array}$ \\
\hline & & Фінансові & $\begin{array}{l}\text { - грошові кошти } \\
\text { - короткострокові фінансові інвести- } \\
\text { ції } \\
\text { - дебіторська заборгованість }\end{array}$ \\
\hline & \multirow[b]{2}{*}{$\begin{array}{l}\text { За рівнем варіабе- } \\
\text { льності розміру }\end{array}$} & Постійні & $\begin{array}{l}\text { постійно перебувають у розпоряджен- } \\
\text { ні підприємства }\end{array}$ \\
\hline & & Тимчасові & $\begin{array}{l}\text { обсяг коливається відповідно до се- } \\
\text { зонних потреб виробництва та реалі- } \\
\text { зації продукції або до циклічних змін } \\
\text { кон'юнктури ринку }\end{array}$ \\
\hline \multirow{12}{*}{$\begin{array}{l}\text { Бубняк I.M. } \\
\text { [14] }\end{array}$} & \multirow{3}{*}{$\begin{array}{c}\text { За характером фі- } \\
\text { нансових джерел } \\
\text { формування }\end{array}$} & \multicolumn{2}{|r|}{ 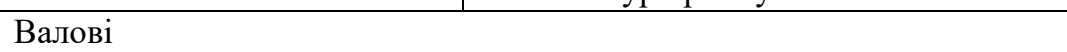 } \\
\hline & & \multicolumn{2}{|l|}{ Чисті } \\
\hline & & \multicolumn{2}{|l|}{ Власні } \\
\hline & \multirow[t]{2}{*}{$\begin{array}{c}\text { За характером } \\
\text { участі в операцій- } \\
\text { ному процесі }\end{array}$} & $\begin{array}{l}\text { Оборотні активи, які обслу- } \\
\text { говують виробничий цикл }\end{array}$ & $\begin{array}{l}\text { - запаси сировини, матеріалів і напів- } \\
\text { фабрикатів } \\
\text { - обсяг незавершеного виробництва } \\
\text { - запаси готової продукції }\end{array}$ \\
\hline & & $\begin{array}{l}\text { Оборотні активи, які обслу- } \\
\text { говують фінансовий цикл }\end{array}$ & дебіторська заборгованість \\
\hline & \multirow{2}{*}{$\begin{array}{l}\text { За періодом функ- } \\
\text { ціонування }\end{array}$} & \multicolumn{2}{|c|}{ Постійна частина оборотних активів } \\
\hline & & \multicolumn{2}{|c|}{ Змінна частина оборотних активів } \\
\hline & \multirow{5}{*}{$\begin{array}{l}\text { Види оборотних } \\
\text { активів }\end{array}$} & \multicolumn{2}{|c|}{$\begin{array}{l}\text { Запаси сировини, матеріалів та напівфабрикатів, незавершене вироб- } \\
\text { ництво }\end{array}$} \\
\hline & & \multicolumn{2}{|c|}{ Запаси готової продукції } \\
\hline & & Дебіторська заборгованість & $\begin{array}{l}\text { - за товари, роботи, послуги } \\
\text { - за розрахунками } \\
\text { - інша }\end{array}$ \\
\hline & & Грошові кошти & $\begin{array}{l}\text { - в національній } \\
\text { - в іноземній валютах }\end{array}$ \\
\hline & & \multicolumn{2}{|l|}{ Інші оборотні активи } \\
\hline
\end{tabular}




\begin{tabular}{|c|c|c|c|}
\hline & & & Продовження табл.2 \\
\hline \multirow[b]{2}{*}{ Автор } & \multicolumn{3}{|c|}{ Класифікації оборотних активів } \\
\hline & $\begin{array}{c}\text { Класифікаційна } \\
\text { ознака }\end{array}$ & \multicolumn{2}{|c|}{ Види оборотних активів } \\
\hline \multirow{7}{*}{$\begin{array}{c}\text { Ярошевич Н.Б. } \\
{[15, \text { с. } 105]}\end{array}$} & \multirow{2}{*}{$\begin{array}{l}\text { Залежно від їхньої } \\
\text { участі в кругообі- } \\
\text { гу коштів }\end{array}$} & \multicolumn{2}{|l|}{ Оборотні виробничі фонди } \\
\hline & & \multicolumn{2}{|l|}{ Фонди обігу } \\
\hline & \multirow{2}{*}{$\begin{array}{l}\text { За методами пла- } \\
\text { нування, принци- } \\
\text { пами організації та } \\
\text { регулювання }\end{array}$} & \multicolumn{2}{|l|}{ Нормовані } \\
\hline & & \multicolumn{2}{|l|}{ Ненормовані } \\
\hline & \multirow{3}{*}{$\begin{array}{l}\text { За джерелами фо- } \\
\text { рмування }\end{array}$} & \multicolumn{2}{|l|}{ Власні та прирівняні до власних } \\
\hline & & \multicolumn{2}{|l|}{ Залучені } \\
\hline & & \multicolumn{2}{|l|}{ Інші } \\
\hline \multirow{12}{*}{$\begin{array}{l}\text { Бланк I.O. } \\
\text { [16] }\end{array}$} & \multirow{3}{*}{$\begin{array}{l}\text { За характером фі- } \\
\text { нансових джерел } \\
\text { формування }\end{array}$} & \multicolumn{2}{|l|}{ Валові } \\
\hline & & \multicolumn{2}{|l|}{ Чисті } \\
\hline & & \multicolumn{2}{|c|}{ Власні } \\
\hline & \multirow{5}{*}{ За видами } & \multicolumn{2}{|c|}{ Запаси сировини, матеріалів, напівфабрикатів } \\
\hline & & \multicolumn{2}{|c|}{ Запаси готової продукції } \\
\hline & & \multicolumn{2}{|l|}{ Дебіторська заборгованість } \\
\hline & & \multicolumn{2}{|l|}{ Грошові активи } \\
\hline & & \multicolumn{2}{|l|}{ Інші види оборотних активів } \\
\hline & За характером & \multicolumn{2}{|c|}{ Оборотні активи, які обслуговують виробничий цикл підприємства } \\
\hline & $\begin{array}{l}\text { участ1 в операций- } \\
\text { ному процесі }\end{array}$ & Оборотні активи, що обслуго & ують фінансовий цикл підприємства \\
\hline & За періодом функ- & Постійна частина оборотних & ктивів \\
\hline & ціонування & Змінна частина оборотних ак & ивів \\
\hline & & Запаси сировини, матеріалів, & гапівфабрикатів \\
\hline & За формою існу- & Запаси готової продукції & \\
\hline & вання & Поточна дебіторська заборгог & аність \\
\hline Канцедал Н.Ю. & & Інші оборотні активі & \\
\hline Клімович I.M. & За характером & Оборотні активи, що обслуго & ують виробничій цикл підприємства \\
\hline $\begin{array}{c}\text { Ганін B.I. } \\
\text { [17] }\end{array}$ & $\begin{array}{l}\text { участі в операцій- } \\
\text { ному процесі }\end{array}$ & Оборотні активи, що обслуго & ують фінансовий (грошовий) цикл \\
\hline & За періодом функ- & Постійна частина оборотних & ктивів \\
\hline Бутинець Т.А. & ціонування & Зміна частина оборотних акти & \\
\hline$[18]$ & & Нормовані & \\
\hline & За методами & Ненормовані & \\
\hline Носов П.Л., & & Високоліквідні & \\
\hline Купалова Г.I. & за ступенем л1кв1- & Середньоліквідні & \\
\hline$[19]$ & & Низьколіквідні & \\
\hline & & За мінімальним ризиком & \\
\hline & за ступенем ризи- & За середнім ризиком & \\
\hline & & За високим ризиком & \\
\hline & & $\begin{array}{l}\text { Запаси товарно- } \\
\text { матеріальних цінностей }\end{array}$ & $\begin{array}{l}\text { - виробничі запаси } \\
\text { - незавершене виробництво } \\
\text { - готова продукція } \\
\text { - товари }\end{array}$ \\
\hline Савченко А.M. & $\begin{array}{c}\text { Відповідно до } \\
\text { НП(С)БО } 1 \text { «Зага- }\end{array}$ & Поточні фінансові інвестиції & $\begin{array}{l}\text { фінансові інвестиції підприємства в } \\
\text { різні фондові та грошові інструменти } \\
\text { на строк менше одного року }\end{array}$ \\
\hline [20] & $\begin{array}{c}\text { фінансової звітно- } \\
\text { сті» }\end{array}$ & $\begin{array}{l}\text { Грошові кошти та їх еквіва- } \\
\text { ленти }\end{array}$ & $\begin{array}{l}\text { - грошові кошти підприємства в касі } \\
\text { - грошові кошти підприємства на по- } \\
\text { точних рахунках в банках } \\
\text { - еквіваленти грошових коштів }\end{array}$ \\
\hline & & Дебіторська заборгованість & \\
\hline & & Інші види оборотних активів & $\begin{array}{l}\text { у тому числі витрати майбутніх періо- } \\
\text { дів }\end{array}$ \\
\hline
\end{tabular}




\begin{tabular}{|c|c|c|c|}
\hline & & & Продовження таб. \\
\hline \multirow[b]{2}{*}{ Автор } & \multicolumn{3}{|c|}{ Класифікації оборотних активів } \\
\hline & $\begin{array}{c}\text { Класифікаційна } \\
\text { ознака }\end{array}$ & \multicolumn{2}{|c|}{ Види оборотних активів } \\
\hline & Залежно від участі & \multicolumn{2}{|c|}{ Оборотні активи у сфері виробництва } \\
\hline & в кругообігу & \multicolumn{2}{|c|}{ Оборотні активи у сфері обігу } \\
\hline & \multirow{5}{*}{ За видами } & \multicolumn{2}{|c|}{ Запаси сировини, матеріалів, напівфабрикатів } \\
\hline & & \multicolumn{2}{|c|}{ Запаси готової продукції } \\
\hline & & \multicolumn{2}{|c|}{ Дебіторська заборгованість } \\
\hline & & \multicolumn{2}{|c|}{ Грошові кошти } \\
\hline & & \multicolumn{2}{|c|}{ Інші } \\
\hline & За способом від- & \multicolumn{2}{|c|}{ Матеріальні оборотні активи (запаси) } \\
\hline & биття в балансі & \multicolumn{2}{|c|}{ Дебіторська заборгованість (кошти у розрахунках) } \\
\hline & підприємства & \multicolumn{2}{|c|}{ Грошові кошти } \\
\hline & За формами функ- & \multicolumn{2}{|c|}{ Матеріальні } \\
\hline & ціонування & \multicolumn{2}{|c|}{ Фінансові } \\
\hline & За періодом функ- & \multicolumn{2}{|c|}{ Постійна частина оборотних активів } \\
\hline & ціонування & \multicolumn{2}{|c|}{ Змінна частина оборотних активів } \\
\hline & За характером & \multicolumn{2}{|c|}{ Валові } \\
\hline & джерел формуван- & \multicolumn{2}{|l|}{ Чисті } \\
\hline & & \multicolumn{2}{|c|}{ Власні } \\
\hline & & \multicolumn{2}{|c|}{ З високою швидкістю обігу } \\
\hline & За швидк1стю об1- & \multicolumn{2}{|c|}{ З середньою швидкістю обігу } \\
\hline & & \multicolumn{2}{|c|}{ З низькою швидкістю обігу } \\
\hline & & \multicolumn{2}{|c|}{ Абсолютно ліквідні } \\
\hline & За ступенем л1кв1- & \multicolumn{2}{|c|}{ Швидко ліквідні } \\
\hline & & Мало лі & \\
\hline & & Мінімал & \\
\hline & За рівнем цінності & Середнь & \\
\hline & & Потенці & цінності \\
\hline & & Активи & \\
\hline Донін Є.О. & За рівнем ризиків & Активи & \\
\hline [21] & & Активи & Іком \\
\hline & & Активи & \\
\hline & За видами ризиків & Активи & ня боргів \\
\hline & & Активи & \\
\hline & За ступенем захи- & Oборотн & ються інфляційним втратам \\
\hline & $\begin{array}{c}\text { щеност1 в1д 1нфля- } \\
\text { ції }\end{array}$ & Обороть & ься інфляційним втратам \\
\hline & & Високог & \\
\hline & За рівнем прибут- & Середнь & \\
\hline & ковості & Неприбу & \\
\hline & & Збитков & \\
\hline & За сферами вико- & Облік & $\begin{array}{l}\text { - за способом відбиття в балансі під- } \\
\text { приємства } \\
\text { - за періодом функціонування } \\
\text { - за формами функціонування } \\
\text { - за характером джерел формування } \\
\text { - за ступенем використання } \\
\text { - за джерелами формування } \\
\text { - за ступенем ліквідності } \\
\text { - за ступенем керованості }\end{array}$ \\
\hline & ристання & Аналіз & $\begin{array}{l}\text { - за способом відбиття в балансі під- } \\
\text { приємства } \\
\text { - за періодом функціонування } \\
\text { - за формами функціонування } \\
\text { - за характером джерел формування } \\
\text { - за ступенем використання } \\
\text { - за джерелами формування } \\
\text { - за ступенем ліквідності } \\
\text { - за ступенем керованості }\end{array}$ \\
\hline
\end{tabular}




\begin{tabular}{|c|c|c|c|}
\hline \multirow[b]{3}{*}{ Автор } & & & Продовження табл \\
\hline & \multicolumn{3}{|c|}{ Класифікації оборотних активів } \\
\hline & $\begin{array}{c}\text { Класифікаційна } \\
\text { ознака }\end{array}$ & \multicolumn{2}{|c|}{ Види оборотних активів } \\
\hline \multirow[b]{2}{*}{$\begin{array}{c}\text { Донін С.О. } \\
{[21]}\end{array}$} & & Аудит & $\begin{array}{l}\text { - за характером джерел формування } \\
\text { - за ступенем використання } \\
\text { - за формами функціонування } \\
\text { - за джерелами формування } \\
\end{array}$ \\
\hline & & Менеджмент & $\begin{array}{l}\text { - за видами } \\
\text { - залежно від участі в кругообігу } \\
\text { - за ступенем керованості } \\
\text { - за ступенем ліквідності } \\
\text { - за рівнем цінності } \\
\text { - за рівнем ризиків } \\
\text { - за видами ризиків } \\
\text { - за ступенем захищеності від інфля- } \\
\text { ції } \\
\text { - за рівнем прибутковості }\end{array}$ \\
\hline
\end{tabular}

* Узагальнено на підставі аналізу джерел [12-21]

Проведене дослідження підтверджує велику кількість підходів до класифікації оборотних активів підприємства, але важливим є вибір такої класифікаціï, яка враховує сучасні аспекти функціонування підприємства в зовнішньому середовищі та ефективне управління його активами та ефективним використанням капіталу.

Нормативно-правове регулювання обліку оборотних активів дає змогу відображати достовірну й повну інформацію, тому задля забезпечення належного контролю за наявністю та використанням оборотних активів, необхідно чітко дотримуватися всіх встановлених нормативно-правових актів. Так, основним таким законодавчим актом є Закон України «Про бухгалтерський облік та фінансову звітність в Україні» від 16.07.1999р №996-XIV зі змінами та доповненнями, який регулює систему ведення бухгалтерського обліку та складання фінансової звітності, а також їх державне регулювання на підприємстві в цілому [22]. Крім того, до нормативно-правової бази можна віднести також Конституцію України; укази, розпорядження та постанови Президента та Кабінету Міністрів України; нормативно-правові акти, наприклад, інструкції та накази, методичні рекомендації Міністерства фінансів України; рішення та накази, які розробляються безпосередньо на підприємстві, наприклад, Наказ про облікову політику підприємства. Що стосується формування даних про оборотні активи у бухгалтерському обліку та фінансовій звітності, то підприємство може самостійно обирати як національні, так й міжнародні Положення (стандарти) бухгалтерського обліку (якщо інше не встановлено законом), які будуть в майбутньому регулювати його діяльність. До таких основних положень належать такі нормативно-правові акти [23]: звітності;

- НП(С)БО 1 «Загальні вимоги до фінансової

- П(С)БО 9 «Запаси»;

- П(С)БО 10 «Дебіторська заборгованість»;

- П(С)БО 13 «Фінансові активи»;

- МСБО 1 «Подання фінансової звітності»
- МСБО 2 «Запаси»;

- МСБО 7 «Звіт про рух грошових коштів»;

- МСБО 8 «Облікові політики, зміни в облікових оцінках та помилки»;

- МСБО 18 «Дохід»;

- МСБО 32 «Фінансові інструменти: розкриття та подання»;

- МСБО 39 «Фінансові інструменти: визнання та оцінка».

Основною формою фінансової звітності, яка надає інформацію про надходження та витрачання грошових коштів, які здійснюються в процесі господарської діяльності, є Форма №3 «Звіт про рух грошових коштів» за звітний період, який відображає рух грошових коштів від трьох основних видів діяльності: операційної, інвестиційної та фінансової. Дослідження показало, що підприємство може вести облік та подавати звітність за національними чи міжнародними зразками, але правила, які зазначаються в цих положеннях мають відмінні риси. Наприклад, більшою мірою в Україні застосовуються положення, які регулюють складання та подання «Звіту про рух грошових коштів», які наведенні у НП(С)БО 1 «Загальні вимоги до фінансової звітності» [1]. Що стосується іноземних країн, то вони переважно застосовують МСБО 7 «Звіт про рух грошових коштів» [24].

Спільною рисою українських та зарубіжних стандартів є будова звіту, що передбачає наявність таких розділів $[1 ; 23 ; 24]$ :

1. Рух коштів у результаті операційної діяльності. Згідно з НП(С)БО 1 «операційна діяльність»це основна діяльність підприємства та інші іiі види, що не відносяться до інвестиційної та фінансової діяльності, тому під основною діяльністю можна розуміти всі господарські операції та процеси, які пов'язані 3 виробництвом та реалізацією продукції. Саме вона забезпечує основну частку доходу. За НП(С)БО сплата податку на прибуток входить до складу витрат операційної діяльності. Але при використанні міжнародних стандартів, грошові потоки, які виникають від податку на прибуток, відносять до грошових 
коштів від операційної діяльності лише тоді, коли їх не можна ототожнити 3 фінансовою або інвестиційною діяльністю.

2. Рух коштів у результаті інвестиційної діяльності. В даному розділі існують відмінності, оскільки в НП(С)БО 1 термін «інвестиційна діяльність» трактується як придбання та реалізація тих необоротних активів, а також тих фінансових інвестицій, які не $\epsilon$ складовою частиною еквівалентів грошових коштів [1], але інвестиційна діяльність в МСБО 7 не включає інвестиції, які вважаються грошовими еквівалентами, тому що міжнародні стандарти визначають інвестицію як еквівалент грошових коштів, коли вона вільно конвертується у певну суму грошових коштів та характеризується незначним ризиком зміни вартості. Згідно з вище зазначеним, можна зробити висновок, що МСБО 7 відносить поточні фінансові інвестиції до складу операційної діяльності.

3. Рух коштів у результаті фінансової діяльності показує, що фінансова діяльність - це «діяльність, яка призводить до змін у складі та розмірі власного або позикового капіталів підприємства». Таке визначення наведене у НП(С)БО 1, тому що національні стандарти обліку відносять банківські позики, зокрема овердрафти, до фінансової діяльності. Міжнародні стандарти обліку банківські позики відносять до фінансової діяльності, але все, що стосується банківських овердрафтів, які погашаються за вимогою, відображається у складі операційної діяльності, так як вони є невід'ємною частиною управління грошовими потоками, що з нею пов'язано.

4. Дослідження праць вчених та стандартів обліку підтверджує, що Форма «Звіту про рух грошових коштів» $є$ регламентованою та обов'язковою для всіх підприємств, які ведуть облік за НП(С)БО, але тих, хто застосовує МСБО 7 форма цього звіту описується лише в загальному вигляді.

Аналіз національних та міжнародних стандартів обліку, дослідження науковців показують, що такі відмінності можна побачити і у визначенні елементів оборотних активів [1;24]. Так, відповідно до НП(С)БО 1 елемент «грошові кошти» охоплює готівку, кошти на рахунках в банках і депозити до запитання, а МСБО 7 до грошових коштів відносить лише готівку в касі та депозити до запитання. Для зазначення операцій надходження та видачі грошових коштів національний стандарт обліку використовує поняття «рух грошових коштів», а міжнародний «грошові потоки», хоча зміст термінів має однакове значення.

Наступним елементом та складовою оборотних активів для дослідження $є$ запаси. Так, облік запасів в Україні та відображення інформації про них у звітності здійснюється із використанням П(С)БО 9 «Запаси» [25], а в зарубіжних країнах за допомогою МСБО 2 «Запаси» [26; 27]. Операції, які пов'язані із надходженням, зберіганням та використанням запасів відображаються на рахунках 2 класу «Запаси». П(С)БО 9 трактує термін «запаси» як «активи, що утримуються для подальшого продажу за умов звичайної господарської діяльності; перебувають у про- цесі виробництва 3 метою подальшого продажу продукту виробництва; утримуються для споживання під час виробництва продукції, виконання робіт та надання послуг, а також управління підприємством» [25]. Дане положення зазначає, що куплені або виготовлені на підприємстві запаси обліковуються за первісною вартістю, яка є їх собівартістю. Але необхідно визначити, як відрізняються витрати, які належать до собівартості продукції в залежності від національного або міжнародного стандартів? Так, згідно з П(С)БО 9 «Запаси» до первісної вартості відносять [25]:

1) суму, яку потрібно оплатити постачальнику та інші витрати, пов'язані з пошуком необхідних запасів (інформаційні, посередницькі тощо);

2) ввізне мито;

3) непрямі податки, що пов'язані із придбанням запасів та не будуть в подальшому відшкодовані підприємству;

4) витрати на перевезення, завантаження/розвантаження запасів, їх страхування;

5) інші витрати, що пов’язані з купівлею запасів.

Якщо на підприємстві застосовують МСБО 2 «Запаси», то собівартість (початкова вартість) виготовленої продукції буде включати в себе [26]:

1) ціну придбання;

2) імпортне мито;

3) інші податки, які не будуть відшкодовуватися податковими органами;

4) транспортні та експедиторські витрати;

5) інші витрати, що будуть понесені при купівлі запасів.

Таке поняття, як первісна вартість в МСБО 2 відсутнє. Для того, щоб здійснити оцінку відпуску запасів або їх вибуття П(С)БО 9 пропонує використовувати один з методів: ФІФО, ідентифікованої собівартості одиниці запасу, середньозваженої собівартості, нормативних затрат або за ціною продажу. Метод списання запасів, що використовується підприємством, повинен бути описаний в обліковій політиці [25]. Дослідження показало, що найчастіше підприємства застосовують метод ФІФО, середньозваженої собівартості та ідентифікованої собівартості конкретної партії активів, але все це залежить від особливостей його діяльності. Якщо ж підприємство застосовує МСБО 2, то можливі наступні варіанти списання запасів: метод конкретної ідентифікації, метод ФІФО, метод ЛІФО (last-in, first-out), метод стандартних витрат та метод роздрібних цін [26].

Отже, значні відмінності в обліку вибуття запасів відсутні, хоча П(С)БО 9 надає більший вибір методів, однак деякі 3 них застосовуються дуже рідко. Що до оцінки запасів на дату балансу, то запаси оцінюються за найменшою 3 двох вартостей: первісною або чистою вартістю реалізації, якщо обрано П(С)БО 9 [25], а МСБО 2 оцінює запаси виключно за чистою реалізаційною вартістю [26].

Існують також певні розбіжності при обліку запасів. Так, наприклад, згідно 3 вітчизняним законодавством, облік запасів, які надійшли до моменту переходу права власності, проводиться інакше, ніж 
тих матеріалів, на які суб'єкт господарювання має всі права. Запаси, на які підприємство не має права власності, повинні обліковуватися на позабалансових рахунках. Міжнародні стандарти для малих та середніх підприємств більш лояльні в даному аспекті, тому що запаси визнаються активами та обліковуються на балансі підприємства незалежно від права власності [26]. Таким чином, можна констатувати, що між П(С)БО 9 та МСБО 2 майже немає відмінностей. Спільними рисами обох стандартів $є$ визначення терміну «запаси», умови їх визнання, рекомендації, що стосуються методів оцінки запасів та основні поняття, пов'язані $з$ даним видом активів. Але в національному положенні надається більша деталізація. До основних відмінних рис можна віднести склад запасів та склад витрат, які формують собівартість. Наприклад, в П(С)БО 9 відсутне вирахування із витрат на закупівлю запасів вартості торгових знижок, повернення платежів та аналогічних статей, що наявно в МСБО 2 $[25 ; 26]$.

Важливим елементом оборотних активів $\epsilon$ дебіторська заборгованість. Для правильного облікового відображення використовуються такі нормативні документи, як: в Україні - П(С)БО 10 «Дебіторська заборгованість» та П(С)БО 13 «Фінансові інструменти» [28; 29], у зарубіжних країнах - МСБО 1 «Подання фінансової звітності», МСБО 8 «Облікові політики, зміни в облікових оцінках та помилки», МСБО 18 «Дохід», МСБО 32 «Фінансові інструменти: розкриття та подання» та МСБО 39 «Фінансові інструменти: визнання та оцінка» [30-34].

Так, в МСБО дебіторська заборгованість «визнається фінансовим активом, який дає конкретне право на отримання цінних паперів чи грошових коштів від іншого суб'єкта господарювання». Порядок оцінки та визнання дебіторської заборгованості подається в П(С)БО 10 «Дебіторська заборгованість», П(С)БО 13 «Фінансові інструменти» та МСБО 39 «Фінансові інструменти: визнання та оцінка». Згідно 3 національним стандартом існує два положення, що регулюють визнання і оцінку більшої частини дебіторської заборгованості, яка виступає в якості фінансового активу [28]. Однак у даних стандартах не вказано взаємних посилань, тому може здатися, що вони застосовуються до різних активів. Окремого стандарту щодо визнання та оцінки дебіторської заборгованості у міжнародних стандартах немає, а уся необхідна для розкриття інформація подається в МСБО 39, тобто така заборгованість вважається одним 3 видів фінансових інструментів [34].

Порівнюючи дані стандарти - П(С)БО 10 [28] та МСБО 39 [34] - можна помітити декілька розбіжностей:

- оцінка дебіторської заборгованості за П(С)БО здійснюється за первісною вартістю (або чистою вартістю реалізації), а згідно МСБО - за справедливою вартістю;

- національні стандарти визнають дебіторську заборгованість активом, якщо існує ймовірність отримання майбутніх економічних вигід і можливо достовірно визначити іiі суму, а міжнародні стандарти

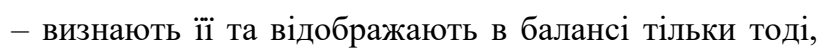
коли підприємство стає стороною контрактних зобов'язань i отримує юридичне право одержувати грошові кошти або інші цінності.

Дослідження праць вчених [27; 35-38] та національних [1; 23] і міжнародних стандартів бухгалтерського обліку [24; 26; 30-34] показало, що незважаючи на ці істотні відмінності в стандартах, в них можна простежити і спільні риси. Наприклад, за обома стандартами у фінансовій звітності дебіторська заборгованість відображається у складі поточних активів та поділяється на короткострокову і довгострокову.

Висновки та перспективи подальших досліджень. В результаті проведеного дослідження отримано певні результати і висновки, що мають важливе значення при визначенні підприємством власної облікової політики та веденні обліку такого значного аспекту діяльності, як оборотні активи:

- оборотні активи мають велику вагу в загальній сукупності активів, вони втілюють в собі матеріальні цінності та грошові кошти, які обслуговують усі види господарської діяльності підприємства та призначені для споживання протягом одного року, а інформацію про стан і склад оборотних активів можна знайти в формах фінансової звітності №1 «Баланс (Звіт про фінансовий стан)», Форма №3 «Звіт про рух грошових коштів» та в Формі №5 «Примітки до річної фінансової звітності;

- у зв'язку з наближенням українських стандартів бухгалтерського обліку до міжнародних, законодавство України стає ближчим до економічно розвинених країн, що дозволяє спростити організацію обліку, зробити інформацію більш прозорою та простою для використання користувачами із різних країн, але на даний момент все ж таки ще існують розбіжності 3 організації обліку в Україні в порівняні 3 іншими іноземними країнами;

- проведене дослідження аспектів обліку елементів оборотних активів: грошових коштів, запасів, дебіторської заборгованості за міжнародними та національними стандартами дозволило виявити спільні риси та відмінності у визначенні, формуванні складу, оцінки тощо, що суттєво впливає на організацію бухгалтерського обліку на підприємстві при обранні тих або інших стандартів обліку й основними причинами таких відмінностей є специфічні риси національної системи обліку та податкового законодавства;

- дослідження підтвердило, що поняття «оборотні активи» мають широке трактування у публікаціях вчених, а також велику кількість підходів до класифікації оборотних активів підприємства та, на нашу думку, найпоширенішу класифікацію оборонних активів запропонував саме С.О. Донін [21] $з$ точки зору сучасних умов функціонування підприємства та їі фінансової стійкості й управління ефективністю використання оборотного капіталу, якій вкладено в його оборотні активи, основними елементами яких $\epsilon$ грошові кошти, запаси та дебіторська заборгованість, що потребують уваги та ефективного управління; 
- ефективне використання та управління оборотними активами та їх елементами не можливе без вивчення та знання сучасного нормативного законодавства при формуванні облікової політики підприємства та ефективної організації бухгалтерського обліку на підприємстві;

- проведений аналіз окремих аспектів НП(С)БО та М(С)БО щодо організації обліку оборот- них активів та відображення їх у фінансовій звітності i їх класифікації, підтверджує актуальність проведеного дослідження відповідно до поставленої мети та потребує в подальшому аналізу методів управління важливими елементами оборотних активів й політики управління ними, що застосовуються в управлінському обліку, який в теперішній час має стратегічний вектор розвитку і застосування.

\section{Література}

1. Загальні вимоги до фінансової звітності: Національне положення (стандарт) бухгалтерського обліку 1: затв. наказом Мінфіну від 07.02.2013 №73 за станом на 31.05.2019. URL: httpbuhgalterskogo/nacionalynepologhennya-standartu-102buhgalter911.com/normativnaya-baza/instr-plan-rah/standart1081.html (дата звернення 25.09.2020).

2. Слав’юк Р. А. Фінанси підприємств: навчальний посібник. Луцьк: Ред.-вид. відд. «Вежа» Волин. держ. ун-ту ім. Лесі Українки, 2001. 460с.

3. Нашкерська Г.В. Бухгалтерський облік : навч.посібник. К. : Центр навчальної літератури, 2004. 464 c.

4. Демченко Т. А. Оборотні активи та їх відображення в бухгалтерському обліку і фінансовій звітності // Актуальні проблеми економіки. 2007. №9. 227 с.

5. Ковалев, В.В. Финансы предприятий: учебник. М.: ТК Велби, 2004. 352 с.

6. Бланк И. А. Управление активами и капиталом предприятия. К.: Ника-центр, Эльга, 2003. 448 с.

7. Ермасова Н. Б. Финансовый менеджмент. М.: Юрайт-Издат, 2007. 192 с.

8. Кирейцев Г. Г. Финансовый менеджмент: учеб. пособие. К.: ЦУЛ, 2006. 496 с.

9. Бухгалтерський фінансовий облік: підручник для студентів спеціальності «Облік і аудит» вищих навчальних закладів / Бутинець Ф.Ф. та ін.; під заг. Ред. Ф.Ф. Бутинця. 8-ме вид., доп. і перероб. Житомир: ПП «Рута», 2009.912 с.

10. Брейли Р., Майерс С. Принципы корпоративных финансов. М.: Олимп-Бизнес, 1997. 1088 с.

11. Боди 3., Мертон. Финансы Р. М.: Вильямс, 2007. 592 с.

12. Тарасенко O.I., Любенко H.M. Фінанси підприємств: підручник. URL: https://pidru4niki.com/84830/finansi/oborotni_aktivi_pidpriyemstv\#72 (дата звернення: 25.09.2020).

13. Фінансовий аналіз: навч. посіб. / Білик М.Д. та ін. К.: КНЕУ, 2005. 592 с.

14. Бубняк I.M. Фінансовий менеджмент. URL:

https://lubbook.org/book_359_glava_51_51._Sutn\%D1\%96stta_klasif\%D1\%96ka\%D1\%81\%EF\%ВF\%BD.html (дата звернення: 25.09.2020).

15. Ярошевич Н. Б. Фінанси підприємств: навч. посібник. К. : Знання, 2012. 341 с.

16. Бланк І.А. Управління використанням капіталу: навч. посібник. К. : Ніка-Центр: Ельга, 2000. 651 с.

17. Канцедал Н.Ю., Клімович І.М., Ганін В.І. Окремі питання управління оборотними активами підприємства // Економіка та держава, № 11/2019. С.103-107. doi: 10.32702/2306-6806.2019.11.103

18. Бутинець Т.А. Сучасний стан обліку і документування розрахунків з податку на додану вартість // Проблеми теорії та методології бухгалтерського обліку, контролю і аналізу, №1 (28) / 2014. URL: http://pbo.ztu.edu.ua/article/view/34238 (дата звернення: 25.09.2020).

19. Носов П.Л., Купалова Г.І. Сучасна класифікація оборотних активів // Економіка і держава. № 7. 2014. C. 43-46.

20. Савченко А.М., Матвіюк А.В. Оборотні активи виробничого підприємства в сучасних умовах: обліково-аналітичний аспект // Східна Свропа: Економіка, бізнес та управління. 2019. Вип. 6 (23). С. 698-705.

21. Донін Є.О. Особливості сучасних підходів щодо специфіки класифікації оборотних активів підприємства // Економіка і організація управління. 2018. № 1 (29). С.75-84.

22. Карелов С.П. Законодавчо-нормативне забезпечення обліку та звітностіосновних засобів та методи їх оцінка за його умов // Свропейські перспективи. 2014. №5. С.160-166.

23. Національні положення (стандарти) бухгалтерського обліку в Україні. URL: https://buhgalter911.com/normativnaya-baza/instr-plan-rah/standart-buhgalterskogo/ (дата звернення 25.09.2020).

24. Звіт про рух грошових коштів: Міжнародний стандарт бухгалтерського обліку 7: за станом на січень 2014. URL: https://buhgalter911.com/public/uploads/msfo/MSBO7_01012015.pdf (дата звернення 25.09.2020).

25. Запаси: Положення (стандарт) бухгалтерського обліку 9: затв. наказом Мінфіну від 20.10.1999 №246 за станом на 29.09.2020. URL: https://buhgalter911.com/normativnaya-baza/instr-plan-rah/standartbuhgalterskogo/pologhennya-standart-buhgaltersykogo-1021474.html (дата звернення 25.09.2020).

26. Запаси: Міжнародний стандарт бухгалтерського обліку 2: за станом на травень 2011. URL: https://buhgalter911.com/public/uploads/msfo/MSBO2_01012015.pdf (дата звернення 25.09.2020). 
27. Мурашко Т. Обрання облікових політик // Вісник. Офіційно про податки : Офіційне видання Державної фіскальної служби України. 2016. №22. URL: http://www.visnuk.com.ua/ru/pubs/id/9895 (дата звернення 25.09.2020).

28. Дебіторська заборгованість: Положення (стандарт) бухгалтерського обліку 10: затв. наказом Мінфіну від 08.10.1999 №237 за станом на 29.09.2020. URL: https://buhgalter911.com/normativnaya-baza/instr-planrah/standart-buhgalterskogo/pologhennya-standart-buhgaltersykogo-1021475.html (дата звернення 25.09.2020).

29. Фінансові інструменти: Положення (стандарт) бухгалтерського обліку 13: затв. наказом Мінфіну від 30.11.2001 №559 за станом на 29.09.2020. URL: https://buhgalter911.com/normativnaya-baza/instr-plan-rah/standartbuhgalterskogo/pologhennya-standart-buhgaltersykogo-1021479.html (дата звернення 25.09.2020).

30. Подання фінансової звітності: Міжнародний стандарт бухгалтерського обліку 1: за станом на травень 2017. URL: https://buhgalter911.com/public/uploads/msfo/2019/IAS\%2001_ukr19.pdf (дата звернення 25.09.2020).

31. Облікові політики, зміни в облікових оцінках та помилки: Міжнародний стандарт бухгалтерського обліку 8: за станом на жовтень 2018. URL: https://buhgalter911.com/public/uploads/news/Img_2020/06_2020/2228.06.2020/IAS\%208_ukr.pdf (дата звернення 25.09.2020).

32. Дохід: Міжнародний стандарт бухгалтерського обліку 18: за станом на травень 2011. URL: https://buhgalter911.com/public/uploads/msfo/MSBO18_01012015.pdf (дата звернення 25.09.2020).

33. Фінансові інструменти: розкриття та подання: Міжнародний стандарт бухгалтерського обліку 32. URL: https://buhgalter911.com/public/uploads/msfo/MSBO32_01012015.pdf (дата звернення 25.09.2020).

34. Фінансові інструменти: визнання та оцінка: Міжнародний стандарт бухгалтерського обліку 39: за станом на січень 2005. URL: https://buhgalter911.com/public/uploads/msfo/MSBO39_01012015_2.pdf (дата 3вернення 25.09.2020).

35. Канурна З.Ф. Контроль оборотних активів підприємств машинобудівного комплексу // Міжнародний збірник наукових праць. 2008. № 3 (12). C.246-252. URL: http://pbo.ztu.edu.ua/article/view/68491/64015 (дата звернення 25.09.2020).

36. Коблянська Г.Ю., Ревенко К.О. Порівняльна характеристика П(С)БО 9 «Запаси» і МСБО 2 «Запаси» // Економіка: теорія та практика. 2014. № 2. С. 50-55

37. Колумбет О. Оборотні активи: сутність, класифікація та структура у вітчизняній і зарубіжній практиці // Збірник наукових праць ДЕТУТ. Сер. Економіка та управління. 2013. №23-24. С.324-332

38. Малютяк С. Облік запасів: деякі нюанси застосування П(С)БО та МСБО // Аудитор України. 2015. №7-8(236-237). C.50-53. doi: 10.1016/j.intell.2015.04.006

Куприна Н.М.

кандидат экономических наук, доцент кафредра учета и аудита E-mail:k.natali@ukr.net ORCID ID: 0000-0003-4645-545X

Пчелянская Г.Б. старший преподаватель кафедра учета и аудита E-mail: gaya_od@ukr.net ORCID ID: 0000-0003-0944-986X
Стаття надійшла 6.10.2020 Стаття прийнята до друку 20.10.2020 Доступно в мережі Internet 29.12.2020

Васьковская E.A.

кандидат экономических наук, доцент кафедра учета и аудита

E-mail: v.caterin17@gmail.com ORCID ID: 0000-0001-8093-170X

\section{Величко О.Н.}

студентка 3 курса фракультета экономики, бизнеса и контроля

Одеська національна академія харчових технологій вул. Канатна 112, м. Одеса, Україна, 65039

E-mail: velichko20012001@gmail.com ORCID ID: 0000-0002-8591-878X

\section{ОБОРОТНЫЕ АКТИВЫ ПРЕДПРИЯТИЯ: АСПЕКТЫ БУХГАЛТЕРСКОГО УЧЕТА ПО НАЦІОНАЛЬНИМ И МЕЖДУНАРОДНЫМ СТАНДАРТАМ И ИХ КЛАССИФИКАЦИЯ}

Актуальным аспектом в современных условиях является продолжение реформирования системы бухгалтерского учета в Украине по международным стандартам, что связано с интеграционными процессами на всех уровнях функционирования экономических субъектов экономики и государственной политики и регулирования.

Целью данной статьи является исследование аспектов национальных и международных положений (стандартов) бухгалтерского учета, которые связанны с вопросами организации учета обо- 
ротных активов и отражение их в финансовой отчетности, определение подходов к сущности и классификации данного объекта исследования для эффективного их учета и управления.

В данной публикации проведены исследования и проанализированы подходы к определению сущности категории «оборотные активы», а также таких важных элементов как «денежные средства», «запасы», «дебиторская задолженность» по материалам публикаций ученых и национальным и международным стандартам, определены общие черты и различия в составе данных элементов, подходов в их оценке, аспектов отражения в финансовой отчетности. Исследование подтвердило, что приближение структуры украинских стандартов бухгалтерского учета и формирования финансовой отчетности к международным, законодательство Украины становится ближе к нормативным документам экономически развитых стран и позволяет упростить организацию учета, сделать информацию более прозрачной и простой для всех категорий пользователей, но на данный момент все-таки еще существуют разночтения и трактования в организации учета в Украине по сравнению с другими государствами.

Исследуя подходы к классификации оборотных активов по различным признакам, целям управления и структурным элементам, наиболее распространенную классификацию оборонных активов предложил Е.А. Донин с точки зрения современных условий функционирования предприятия и его финансовой устойчивости, управления эффективностью использования оборотного капитала, которой вложено в его оборотные активы и основные элементы - денежные средства, запасы и дебиторскую задолженность. Доведено, что эффрективное использование и управление оборотными активами и их элементами невозможно без изучения и знания современного нормативного законодательства при формировании учетной политики предприятия и эффективной организации бухгалтерского учета на нем.

Ключевые слова: оборотные активы, элементы оборотных активов, классификация, стандарты бухгалтерского учета, денежные средства, запасы, дебиторская задолженность.

Kuprina $\mathbf{N}$.

Ph.D., Associate Professor

Department of Accounting and Auditing

E-mail:k.natali@ @ukr.net

ORCID ID: 0000-0003-4645-545X

Pchelianska G.

Assistant

Department of Accounting and Auditing

E-mail: gaya_od@ukr.net

ORCID ID: 0000-0003-0944-986X
Vaskovska K.

Ph.D., Associate Professor

Department of Accounting and Auditing

E-mail: v.caterin17@gmail.com

ORCID ID: 0000-0001-8093-170X

Velychko 0.

The student of the third grade of Economy, Business and Control Faculty Odessa National

Odessa National Academy of Food Technologies

Kanatna str., 112, Odesa, Ukraine, 65039

E-mail: velichko20012001@gmail.com ORCID ID: 0000-0002-8591-878X

\section{CURRENT ASSETS OF THE ENTERPRISE: ASPECTS OF ACCOUNTING ON THE NATIONAL AND INTERNATIONAL STANDARDS AND THEIR CLASSIFICATION}

An important aspect in modern conditions is the continuation of the reforming of the accounting system in Ukraine in accordance with international standards, which is associated with integration processes at all levels of functioning of economic entities of the economy and state policy and regulation. The purpose of this article is to study aspects of national and international provisions (standards) of accounting, which are related to the organization of accounting for current assets and their reflection in financial statements, to determine approaches to the essence and classification of this research object for their effective accounting and management.

This publication conducted the research and analyzed the approaches to defining the essence of the category of "current assets", as well as such important elements as "cash", "stocks", "accounts receivable" based on scientific publications and national and international standards, identified common features and differences in the composition of these elements, approaches to their assessment, aspects of reflection in the financial statements. The study confirmed that the approximation of the structure of Ukrainian accounting standards and the formation of financial statements to international ones, the legislation of Ukraine is getting closer to the normative documents of economically developed countries and allows simplifying the organization of accounting, making information more transparent and simple for all categories of users, but at the moment, however, there are discrepancies in interpretations of the organization of accounting in Ukraine in 
comparison to other states. Investigating approaches to the classification of circulating assets according to various criteria, management objectives and structural elements, the most common classification of defense assets was proposed by E.A. Donin from the point of view of the modern conditions of the operation of the enterprise and its financial stability, management of the efficiency of using working capital, which is invested in its current assets and the main elements - cash, stocks and accounts receivable. It has been proved that the effective use and management of circulating assets and their elements is impossible without studying and knowledge of modern regulatory legislation in the formation of an enterprise's accounting policy and effective organization of accounting on it.

Key words: current assets, elements of current assets, classification, accounting standards, cash, stocks, accounts receivable.

\section{References}

1. Zahalni vymohy do finansovoi zvitnosti: Natsionalne polozhennia (standart) bukhhalterskoho obliku 1 vid 07.02.2013 №73 za stanom na 31.05.2019. Retrieved September 25, 2020, from https://buhgalter911.com/uk/normativnaya-baza/instr-plan-rah/standart-buhgalterskogo/nacionalyne-pologhennyastandartu-1021081.html.

2. Slav'iuk, R. A. (2001). Finansy pidpryiemstv. Lutsk: Red.-vyd. vidd. «Vezha» Volyn. derzh. un-tu im. Lesi Ukrainky.

3. Nashkerska, H. V. (2004). Bukhhalterskyi oblik. Kyiv: Tsentr navchalnoi literatury.

4. Demchenko, T. A. (2007). Oborotni aktyvy ta yikh vidobrazhennia v bukhhalterskomu obliku i finansovii zvitnosti. Aktualni problemy ekonomiky, (9).

5. Kovalev, V. V. (2004). Finansyi predpriyatiy. Moscow: TK Velbi.

6. Blank, I. A. (2003). Upravlenie aktivami i kapitalom predpriyatiya. Kyiv: Nika-tsentr, Elga.

7. Ermasova, N. B. (2007). Finansovyiy menedzhment. Moscow: Yurayt-Izdat.

8. Kireytsev, G. G. (2006). Finansovyiy menedzhment. Kyiv: TsUL.

9. Butynets, F. F. (Ed.). (2009). Bukhhalterskyi finansovyi oblik (8th ed.). Zhytomyr: PP «Ruta».

10. Breyli, R., \& Mayers, S. (1997). Printsipyi korporativnyih finansov. Moscow: Olimp-Biznes.

11. Bodi, Z., \& Merton, R. (2007). Finansyi. Moscow: Vilyams.

12. Tarasenko, O. I., \& Liubenko, N. M. Finansy pidpryiemstv. Retrieved September 25, 2020, from https://pidru4niki.com/84830/finansi/oborotni_aktivi_pidpriyemstv\#72

13. Bilyk, M. D. (2005). Finansovyi analiz. Kyiv: KNEU.

14. Bubniak, I. M. Finansovyi menedzhment. Retrieved September 25, 2020, from https://lubbook.org/book_359_glava_51_51._Sutn\%D1\%96stta_klasif\%D1\%96ka\%D1\%81\%EF\%BF\%BD.html

15. Yaroshevych, N. B. (2012). Finansy pidpryiemstv. Kyiv: Znannia.

16. Blank, I. A. (2000). Upravlinnia vykorystanniam kapitalu. Kyiv: Nika-Tsentr; Elha.

17. Kantsedal, N. Yu., Klimovych, I. M., \& Hanin, V. I. (2019). Okremi pytannia upravlinnia oborotnymy aktyvamy pidpryiemstva. Ekonomika ta derzhava, (11), 103-107. doi: 10.32702/2306-6806.2019.11.103

18. Butynets, T. A. (2014). Suchasnyi stan obliku i dokumentuvannia rozrakhunkiv z podatku na dodanu vartist. Problemy teorii ta metodolohii bukhhalterskoho obliku, kontroliu i analizu, (1(28). Retrieved September 25, 2020, from http://pbo.ztu.edu.ua/article/view/34238

19. Nosov, P. L., \& Kupalova, H. I. (2014). Suchasna klasyfikatsiia oborotnykh aktyviv. Ekonomika $i$ derzhava, (7), 43-46.

20. Savchenko, A. M., \& Matviiuk, A. V. (2019). Oborotni aktyvy vyrobnychoho pidpryiemstva v suchasnykh umovakh: oblikovo-analitychnyi aspekt. Skhidna Yevropa: Ekonomika, biznes ta upravlinnia, (6(23), 698-705.

21. Donin, Ye. O. (2018). Osoblyvosti suchasnykh pidkhodiv shchodo spetsyfiky klasyfikatsii oborotnykh aktyviv pidpryiemstva. Ekonomika i orhanizatsiia upravlinnia, (1(29), 75-84.

22. Karelov, S. P. (2014). Zakonodavcho-normatyvne zabezpechennia obliku ta zvitnostiosnovnykh zasobiv ta metody yikh otsinka za yoho umov. Yevropeiski perspektyvy, (5), 160-166.

23. Natsionalni polozhennia (standarty) bukhhalterskoho obliku v Ukraini. Retrieved September 25, 2020, from https://buhgalter911.com/normativnaya-baza/instr-plan-rah/standart-buhgalterskogo/

24.Zvit pro rukh hroshovykh koshtiv: Mizhnarodnyi standart bukhhalterskoho obliku 7: za stanom na sichen 2014. Retrieved September 25, 2020, from https://buhgalter911.com/public/uploads/msfo/MSBO7_01012015.pdf

25. Zapasy: Polozhennia (standart) bukhhalterskoho obliku 9: zatv. nakazom Minfinu vid 20.10.1999 №246 za stanom na 29.09.2020. (2020). Retrieved September 25, 2020, from https://buhgalter911.com/normativnaya-baza/instrplan-rah/standart-buhgalterskogo/pologhennya-standart-buhgaltersykogo-1021474.html 
26. Zapasy: Mizhnarodnyi standart bukhhalterskoho obliku 2: za stanom na traven 2011. Retrieved September 25, 2020, from https://buhgalter911.com/public/uploads/msfo/MSBO2_01012015.pdf

27. Murashko, T. (2016). Obrannia oblikovykh polityk. Visnyk. Ofitsiino pro podatky: Ofitsiine vydannia Derzhavnoi fiskalnoi sluzhby Ukrainy, (22). Retrieved September 25, 2020, from http://www.visnuk.com.ua/ru/pubs/id/9895

28. Debitorska zaborhovanist: Polozhennia (standart) bukhhalterskoho obliku 10: zatv. nakazom Minfinu vid 08.10.1999 №237 za stanom na 29.09.2020. (2020). Retrieved September 25, 2020, from https://buhgalter911.com/normativnaya-baza/instr-plan-rah/standart-buhgalterskogo/pologhennya-standartbuhgaltersykogo-1021475.html

29. Finansovi instrumenty: Polozhennia (standart) bukhhalterskoho obliku 13: zatv. nakazom Minfinu vid 30.11.2001 №559 za stanom na 29.09.2020. (2020). Retrieved September 25, 2020, from https://buhgalter911.com/normativnaya-baza/instr-plan-rah/standart-buhgalterskogo/pologhennya-standartbuhgaltersykogo-1021479.html

30. Podannia finansovoi zvitnosti: Mizhnarodnyi standart bukhhalterskoho obliku 1: za stanom na traven 2017. Retrieved September 25, 2020, from https://buhgalter911.com/public/uploads/msfo/2019/IAS\%2001_ukr19.pdf

31. Oblikovi polityky, zminy v oblikovykh otsinkakh ta pomylky: Mizhnarodnyi standart bukhhalterskoho obliku 8: za stanom na zhovten 2018. Retrieved September 25, 2020, from https://buhgalter911.com/public/uploads/news/Img_2020/06_2020/22-28.06.2020/IAS\%208_ukr.pdf

32. Dokhid: Mizhnarodnyi standart bukhhalterskoho obliku 18: za stanom na traven 2011. Retrieved September 25, 2020, from https://buhgalter911.com/public/uploads/msfo/MSBO18_01012015.pdf

33. Finansovi instrumenty: rozkryttia ta podannia: Mizhnarodnyi standart bukhhalterskoho obliku 32. Retrieved September 25, 2020, from https://buhgalter911.com/public/uploads/msfo/MSBO32_01012015.pdf

34. Finansovi instrumenty: vyznannia ta otsinka: Mizhnarodnyi standart bukhhalterskoho obliku 39: za

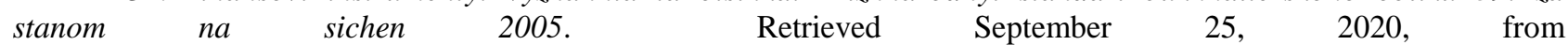
https://buhgalter911.com/public/uploads/msfo/MSBO39_01012015_2.pdf

35. Kanurna, Z. F. (2008). Kontrol oborotnykh aktyviv pidpryiemstv mashynobudivnoho kompleksu. Mizhnarodnyi zbirnyk naukovykh prats, (3(12), 246-252. Retrieved September 25, 2020, from http://pbo.ztu.edu.ua/article/view/68491/64015

36. Koblianska, H. Yu., \& Revenko, K.O. (2014). Porivnialna kharakterystyka P(S)BO 9 «Zapasy» i MSBO 2 «Zapasy». Ekonomika: teoriia ta praktyka, (2), 50-55.

37. Kolumbet, O. (2013). Oborotni aktyvy: sutnist, klasyfikatsiia ta struktura u vitchyznianii i zarubizhnii praktytsi. Zbirnyk naukovykh prats DETUT, (23-24), 324-332.

38. Maliutiak, S. (2015). Oblik zapasiv: deiaki niuansy zastosuvannia P(S)BO ta MSBO. Audytor Ukrainy, (78(236-237), 50-53. doi: 10.1016/j.intell.2015.04.006

Received 6 October 2020

Approved 20 October 2020

Available in Internet 29.12.20

Цитування згідно ДСТУ 8302:2015

Купріна Н.М., Васьковська К.О., Пчелянська Г.Б., Величко О.М. Оборотні активи підприємства: аспекти бухгалтерського обліку за національними та міжнародними стандартами та їх класифікація // Економіка харчової промисловості. 2020. Т.12, вип. 4. С. 65-78. doi: 10.15673/fie.v12i4.1913

Cite as APA style citation

Kuprina, N., Vaskovska, K., Pchelianska, G., \& Velychko O. (2020). Current assets of the enterprise: aspects of accounting on the national and international Standards and their classification. Food Industry Economics, 12(4), 65-78. doi: 10.15673/fie.v12i4.1913 